\title{
Development, Validation and Characterization of Genic Microsatellite Markers in Urochloa Species
}

\author{
Juliana Santos Souza1, Lucimara Chiari2 ${ }^{*}$, Rosangela Maria Simeão², \\ Mariane de Mendonça Vilela², Leonardo Rippel Salgado ${ }^{2}$ \\ ${ }^{1}$ Universidade Anhanguera-Uniderp-Campus Agrárias, Campo Grande, Brazil \\ ${ }^{2}$ Embrapa Gado de Corte, Campo Grande, Brazil \\ Email: *lucimara.chiari@embrapa.br
}

How to cite this paper: Souza, J.S., Chiari, L., Simeão, R.M., de Mendonça Vilela, M. and Salgado, L.R. (2018) Development, Validation and Characterization of Genic Microsatellite Markers in Urochloa Species. American Journal of Plant Sciences, 9, 281295.

https://doi.org/10.4236/ajps.2018.92023

Received: November 27, 2017

Accepted: January 23, 2018

Published: January 26, 2018

Copyright (c) 2018 by authors and Scientific Research Publishing Inc. This work is licensed under the Creative Commons Attribution International License (CC BY 4.0).

http://creativecommons.org/licenses/by/4.0/

\begin{abstract}
Urochloa (syn. Brachiaria) cultivars represent $85 \%$ of tropical pastures occupying 114 million hectares of cultivated grasslands in Brazil. Despite the commercial importance of the Urochloa species, low molecular information is available and is far from saturating the genome. Investigating and obtaining more markers associated to characteristics of difficult and late expression can benefit in accelerating breeding programs of more important species. Aiming to increase the number of molecular markers, genic microsatellite markers were obtained from transcriptome of $U$. decumbens and analyzed for their cross-amplification to $U$. brizantha, $U$. humidicola and $U$. ruziziensis. Genic microsatellite markers were isolated from a transcriptome obtained of $U$. decumbens "Basilisk" roots. Specific primers were designed for one hundred lo$\mathrm{ci}$, and 32 were polymorphic presenting polymorphism informative content values ranging of 0.12 to 0.81 (mean 0.54). Amplified microsatellite regions yield an average of 4.44 alleles per locus (ranging of 1 to 13). Cross-amplification to $U$. brizantha, $U$. humidicola and $U$. ruziziensis were successfully performed, although the number of the loci transferred varied among them. Multiple Correspondence Analysis revealed three distinct groups separating accessions and species. Four genetic markers presented high potential to distinguish sexual and apomictic accessions of Urochloa and must be further investigated. The genic markers identified in this study are the first set of expressed sequence tagged molecular markers for Urochloa species.
\end{abstract}

\section{Keywords}

Brachiaria, Signalgrass, Simple Sequence Repeat, Transferability, 
Tropical Forage

\section{Introduction}

The genus Urochloa P. Beauv. spp. (syn. Brachiaria (Trin.) Griseb. spp.) comprises about 100 species, distributed in the tropical and subtropical regions in both hemispheres. Urochloa decumbens (Stapf) R.D.Webster (signalgrass), $U$. brizantha (Stapf) Webster (palisadegrass), U. humidicola (Rendle) Morrone \& Zuloaga (koroniviagrass) and U. ruziziensis (R. Germain \& Evrard) Crins (ruzigrass) are the four principal cultivated species in Brazil and were introduced to Brazil in the early 1960s from eastern Africa [1], their major center of origin and diversity. A collection of 430 accessions of 18 species, including the above mentioned, were introduced in 1987 and deposited in germplasm banks of the Empresa Brasileira de Pesquisa Agropecuária-Embrapa (Brazilian Agricultural Research Corporation), aiming at experimental evaluation and use as forage in the new agricultural frontier of the Brazilian Cerrados [2]. The new Urochloa accessions have revealed a significant variability for productivity, nutritional value, spittlebug resistance and adaptation to acid soils. All characteristics are considered for cultivars release, and the new cultivars have promoted a drastic increase of efficiency in Brazilian livestock production, particularly at low-fertility marginal areas [3]. Urochloa cultivars represent $85 \%$ of tropical pastures occupying 114 million hectares of cultivated grasslands in Brazil [4].

Aforementioned species are represented by accessions with apomictic and sexual mode of reproduction, and also by diploid and polyploid individuals [5]. Furthermore, $U$. brizantha, $U$. decumbens and $U$. ruziziensis form an agamic complex [6], meaning they intercross and produce fertile progeny. Based on this, the International Center for Tropical Agriculture (CIAT) and the Empresa Brasileira de Pesquisa Agropecuária (Embrapa) have conducted breeding programs intraspecific and performing interspecific crosses, both based in recurrent selection methods [3] [4].

New cultivars of tropical forages that better comply with the demands of the livestock sector have influenced and stimulated the conduction of breeding programs for the most important commercial species [1]. New tools to facilitate the selection process such as the use of molecular markers (e.g. microsatellites or Simple Sequence Repeats-SSR) associated to characteristics of difficult and later expression have been studied and searched in order to accelerate breeding and resulting genetic gains [7].

Despite the commercial importance of the Urochloa species for tropical grasslands, molecular information has been carried out but still stands far of saturating the genome with markers. Five-hundred primer pairs of SSR markers were obtained for $U$. ruziziensis diploid using a de novo partial genome assembly of single-end Illumina reads and were partially transferable to other cultivars 
of Urochloa [8]. Ninety-three SSR markers were developed for $U$. decumbens from a microsatellite-enriched library [7], of which $>98 \%$ cross-amplified in $U$. ruziziensis and $U$. brizantha accessions. Worthington et al. [9] obtained 706 single nucleotide polymorphism (SNP) markers heterozygous using genotyping by sequence (GBS) in an interspecific progeny of $U$. decumbens $\mathrm{X} U$. ruziziensis. Considering these species genomes are average-sized $1633 \mathrm{Mbp} \cdot \mathrm{C}^{-1}$ and 1230 $\mathrm{Mbp} \cdot \mathrm{C}^{-1}[10]$, respectively, this means one marker per $1.0 \mathrm{Mbp}$, approximately. Therefore, more markers are necessary to perform genetic studies such as saturated linkage mapping, marker-associated and marker-based selection.

Expressed sequence tags-derived simple sequence repeat markers (ESTSSRs) have a number of advantages over genomic SSR markers developed by cloning and sequencing [11]. In Urochloa genus, and particularly in the agamic complex of $U$. brizantha, $U$. decumbens and $U$. ruziziensis, the genic SSR markers are expected to be more transferable and more likely to be associated with characteristics of interest in breeding programs.

The objectives of this study were: 1) to investigate the polymorphism level and occurrence of genic microsatellite obtained from root transcriptome in $U$. decumbens, and 2) to analyze the transferability of genic SSR markers across Urochloa species.

\section{Material and Methods}

\subsection{Plant Materials}

Urochloa decumbens transcriptome was the base for development, validation and characterization of the genic microsatellite markers. Seven $U$. decumbens, including apomictic and sexual accessions were used to characterize the SSR genic markers. Four accessions of $U$. brizantha, three of $U$. ruziziensis and one of $U$. humidicola were tested for cross-amplification. The accessions identification, as recorded in the databases of Embrapa Gado de Corte and Center for Tropical Agriculture-CIAT, their mode of reproduction, origin and ploidy are shown in Table 1.

\subsection{Genic SSR Development}

The transcriptome from $U$. decumbens roots under aluminum stress was obtained to support studies about genetic expression, as described by Salgado et al. [12], and was used to develop transcriptome-derived microsatellite markers.

The searches for genic SSR markers from the contig dataset were performed using MISA (Microsatellite Identification Tool) [13]. The definition of microsatellites was set to 12 -fold (1/12), di (2/6), tri (3/5), tetra (4/5), penta $(5 / 5)$, or hexa (6/4) mononucleotide repeats. After screening, genic SSR markers situated more than $150 \mathrm{bp}$ from both ends of the encompassing unigene were retained and used to design primers with Primer 3 [14]. For this study, mono and dinucleotide genic SSR were excluded, once they would not be suitable for further studies using the available capillary electrophoresis system. 
Table 1. Species and accessions of Urochloa used to characterize microsatellite markers and analyze cross-amplification.

\begin{tabular}{|c|c|c|c|c|c|c|c|c|}
\hline Species & EGC & BRA & CIAT & Origin & MR & Ploidy & Cultivar & Representative character \\
\hline U. decumbens & D06 & 004456 & 16,495 & Kenya & SEX & $2 \mathrm{x}$ & - & - \\
\hline U. decumbens & D07 & 004472 & 16,497 & Kenya & APO & $4 \mathrm{x}$ & - & - \\
\hline U. decumbens & D24 & 004651 & 26,295 & Rwanda & SEX & $2 \mathrm{x}$ & - & - \\
\hline U. decumbens & D35 & 004782 & 26,308 & Rwanda & SEX & $2 \mathrm{x}$ & - & - \\
\hline U. decumbens & $\mathrm{D} 40$ & 004766 & 26,306 & Rwanda & SEX & $2 \mathrm{x}$ & - & - \\
\hline U. decumbens & D61 & 001961 & 16,100 & - & APO & $4 \mathrm{x}$ & - & - \\
\hline U. decumbens & D62 & 001058 & 606 & Uganda & APO & $4 \mathrm{x}$ & "Basilisk" & Aluminum tolerance \\
\hline U. brizantha & B30 & 000591 & 6294 & Kenya & APO & $4 \mathrm{x}$ & "Marandu" & Spittlebug resistance \\
\hline U. brizantha & B112 & 002844 & 16,125 & Ethiopia & APO & $4 \mathrm{x}$ & “BRS Piatã" & $\begin{array}{l}\text { Early flowering and high } \\
\text { seed production }\end{array}$ \\
\hline U. brizantha & B166 & 003891 & 16,467 & Kenya & APO & $4 \mathrm{x}$ & "BRS Paiaguás" & High yield on dry season \\
\hline U. brizantha & B178 & 004308 & 26,110 & Burundi & APO & $5 \mathrm{x}$ & "Xaraés" & Spittlebug resistance \\
\hline U. humidicola & H16 & 005118 & 26,149 & Burundi & APO & $4 \mathrm{x}$ & "BRS Tupi" & Waterlogging tolerance \\
\hline U. ruziziensis & $\mathrm{R} 46^{*}$ & - & - & - & SEX & $4 \mathrm{x}$ & - & Higher nutritional \\
\hline U. ruziziensis & $\mathrm{R} 48^{*}$ & - & - & - & SEX & $4 \mathrm{x}$ & - & $\begin{array}{l}\text { quality and in vitro } \\
\text { digestibility of dry matter }\end{array}$ \\
\hline U. ruziziensis & $\mathrm{R} 50^{*}$ & - & - & - & SEX & $4 \mathrm{x}$ & - & argestionity or ary matter \\
\hline
\end{tabular}

Note: EGC codes from Embrapa Gado de Corte, BRA codes from Embrapa, CIAT codes from Center for Tropical Agriculture, MR mode of reproductionsexual or apomictic, - not available, *artificially tetraploidized genotypes.

Aiming to select molecular markers with the minimum redundancy in Urochloa's genomes, the predicted amplified sequences were submitted to BLASTn against Setaria italica genome using the online platform CoGe: Blast [15] with an e-value threshold of 1E-10. Sequences returning one or two hits were retained and blast matches positions, along $S$. italica genome, were considered to select 100 genic SSR markers distributed all over genome. S. italica genome was chosen as model since it is the most similar genome available in public databases [12].

\subsection{DNA Isolation and Microsatellite Genotyping}

Genomic DNA was isolated from young fresh leaves using the CTAB method [16]. The purity and concentration of the isolated DNA were determined using a NanoDrop 1000 (Thermo Scientific) spectrophotometer and by electrophoresis in a $0.8 \%$ agarose gel that was subsequently stained with ethidium bromide (5 $\mu \mathrm{g} / \mathrm{mL}^{-1}$ ). The polymerase chain reaction (PCR) assays were performed in a MJ Research PTC- $100^{\mathrm{TM}}$ thermocycler in a $25 \mu \mathrm{L}$ final volume of buffer $[20 \mathrm{mM}$ Tris- $\mathrm{HCl}$ ( $\mathrm{pH} 8.4$ ), $50 \mathrm{mM} \mathrm{KCl}$ and $1.5 \mathrm{mM} \mathrm{MgCl}$ ] containing $60 \mathrm{ng}$ of genomic DNA, $0.8 \mu \mathrm{M}$ of each primer (forward and reverse), $150 \mu \mathrm{M}$ dNTPs and $1 \mathrm{U}$ Taq DNA polymerase (Invitrogen). The PCR program consisted of an initial denaturing step at $94^{\circ} \mathrm{C}$ for $5 \mathrm{~min}$ followed by 30 cycles of amplification $\left[94^{\circ} \mathrm{C}(1\right.$ $\min ), " \mathrm{X}$ " $\left.\mathrm{C}(1 \mathrm{~min}), 72^{\circ} \mathrm{C}(1 \mathrm{~min})\right]$ and a final elongation step at $72^{\circ} \mathrm{C}$ for 15 min, being " $X$ " the temperature determined to amplify each locus (Table 2). The 
Table 2. Description of 34 genic microsatellites developed for $U$. decumbens based on a root transcriptome.

\begin{tabular}{|c|c|c|c|c|c|c|c|c|c|c|c|}
\hline \multirow[t]{2}{*}{ Locus } & \multirow[t]{2}{*}{ Primer sequences $\left(5^{\prime}-3^{\prime}\right)$} & \multirow[t]{2}{*}{$\begin{array}{c}\text { Repeat } \\
\text { motif }\end{array}$} & \multirow[t]{2}{*}{$\mathrm{Ta}\left({ }^{\circ} \mathrm{C}\right)^{\mathrm{a}}$} & \multirow[t]{2}{*}{ Size (bp) } & \multirow{2}{*}{$\begin{array}{l}\text { Total } \\
\text { No. } \\
\text { alleles }\end{array}$} & $\begin{array}{c}U . \\
\text { brizantha }\end{array}$ & $\begin{array}{c}U . \\
\text { decumbens } \\
\text { diploid }\end{array}$ & $\begin{array}{c}U . \\
\text { decumbens } \\
\text { tetraploid }\end{array}$ & $\begin{array}{c}U . \\
\text { humidicola }\end{array}$ & $\begin{array}{c}U . \\
\text { ruziziensis }\end{array}$ & \multirow[t]{2}{*}{ PIC } \\
\hline & & & & & & No. alleles & No. alleles & No. alleles & No. alleles & No. alleles & \\
\hline DecSSR181 & $\begin{array}{l}\text { F: } \\
\text { AGTTGGTGTTGGCAATAACTCTG } \\
\text { R: CTTCTTGGCAGTTGAAGCATCT }\end{array}$ & $\operatorname{CGG}\left(3^{*} 5\right)$ & 60 & $180-210$ & 5 & 4 & 1 & 2 & 2 & 3 & 0.60 \\
\hline DecSSR184 & $\begin{array}{l}\text { F: } \\
\text { CCGAACTTGAGTTGTTATTTCCA } \\
\text { R: } \\
\text { AACTGATGGTAACTCTTGGAGCA }\end{array}$ & TGG $\left(3 *^{*}\right)$ & 60 & $120-140$ & 2 & 1 & 1 & 1 & 2 & 1 & 0.12 \\
\hline DecSSR186 & $\begin{array}{l}\text { F: CAGGAACGGGGAGACGAG } \\
\text { R: CTCACCAACGTCGGCCTC } \\
\text { F: }\end{array}$ & CGG $(3 * 5)$ & 60 & $80-90$ & 1 & 1 & 1 & 1 & $x^{b}$ & 1 & $\mathrm{x}$ \\
\hline DecSSR187 & $\begin{array}{l}\text { GGTGCGTACAACAACTACTGATCT } \\
\text { R: CTGTGCACGCTCGCTGAC }\end{array}$ & $\operatorname{GCT}(3 * 5)$ & 62 & $150-170$ & 5 & 2 & 5 & 2 & $\mathrm{x}$ & 2 & 0.66 \\
\hline DecSSR 188 & $\begin{array}{l}\text { F: GTGTGCCTCTGAGACCCAGT } \\
\text { R: CCCAGCTCAGCCAGTACTTC } \\
\text { F: CTCCGCCTTGCAGTACCTC }\end{array}$ & GGA $\left(3^{\star} 5\right)$ & 62 & $120-140$ & 4 & 1 & 1 & 3 & 1 & 1 & 0.31 \\
\hline DecSSR194 & $\begin{array}{l}\text { R: } \\
\text { TGCAGTACAACAACTACCACCTC }\end{array}$ & GCT $(3 * 5)$ & 60 & $110-120$ & 2 & 2 & 2 & 2 & $\mathrm{x}$ & 2 & 0.50 \\
\hline DecSSR195 & $\begin{array}{l}\text { F: GTCCCGGTGGTGGTGTCC } \\
\text { R: GTTCCACCTGATCTCGCTCTC } \\
\text { F: ATTCAGATGCATTTTTCTTCGTC }\end{array}$ & $\mathrm{GGA}(3 * 5)$ & 62 & $90-100$ & 4 & 2 & 1 & 3 & $\mathrm{x}$ & 2 & 0.56 \\
\hline DecSSR199 & $\begin{array}{l}\text { R: } \\
\text { AGCAGCGTATAATAAGCAAGCAC } \\
\text { F: }\end{array}$ & $\mathrm{TCA}\left(3^{*} 5\right)$ & 60 & $140-160$ & 2 & $\mathrm{x}$ & 2 & 2 & $\mathrm{x}$ & 2 & 0.46 \\
\hline DecSSR202 & $\begin{array}{l}\text { CTGCTTCTTATAGATCCGACCAC } \\
\text { R: } \\
\text { TCTTTAGGAGAGGGATCGAGATT }\end{array}$ & TCG $(3 * 5)$ & 60 & $110-150$ & 7 & 1 & 4 & 2 & 1 & 4 & 0.81 \\
\hline DecSSR203 & $\begin{array}{l}\text { F: GTGATGACGGATGCGGTT } \\
\text { R: ACTATCCGACTTCGCCCAC }\end{array}$ & GCG $(3 * 5)$ & 62 & $110-100$ & 4 & 3 & 2 & 4 & $\mathrm{x}$ & 1 & 0.66 \\
\hline DecSSR205 & $\begin{array}{l}\text { F: GAAATCAGAGATGCCCAGACC } \\
\text { R: AGCGAGATCACCACGGAG }\end{array}$ & $\operatorname{CCG}\left(3^{*} 5\right)$ & 62 & $90-110$ & 2 & 1 & 2 & 1 & $\mathrm{x}$ & 1 & 0.14 \\
\hline DecSSR206 & $\begin{array}{l}\text { F: GGTGGTACCCGGAGTTAGAGTT } \\
\text { R: GCTACCACTACGACCAGGACTC } \\
\text { F: }\end{array}$ & $\operatorname{GCC}(3 * 5)$ & 62 & $100-110$ & 3 & 1 & 1 & 2 & 1 & 1 & 0.24 \\
\hline DecSSR211 & $\begin{array}{l}\text { GTATTAATTCACTGGGTGTCGCT } \\
\text { R: CCATCACCTCCATCATAGGC }\end{array}$ & TTG $(3 * 5)$ & 60 & $130-150$ & 4 & 1 & 1 & 1 & 2 & 2 & 0.56 \\
\hline DecSSR212 & $\begin{array}{l}\text { F: GCCGTATCTCCTTCTCCCAC } \\
\text { R: CACTACCCCTCCCTCCTCTC }\end{array}$ & GAG $\left(3^{\star} 5\right)$ & 62 & $110-140$ & 13 & 11 & 5 & 5 & 3 & 4 & 0.84 \\
\hline DecSSR213 & $\begin{array}{l}\text { F: CAGAGGAAAGGAAGCAGCAG } \\
\text { R: GGCATCACCACCGTCTGG } \\
\text { F: AGGAACTGGTGCTCCTTCTTC }\end{array}$ & $\mathrm{CAG}\left(3^{*} 5\right)$ & 62 & $110-130$ & 8 & 7 & 2 & 4 & $\mathrm{x}$ & 3 & 0.81 \\
\hline DecSSR214 & $\begin{array}{l}\text { R: } \\
\text { TCCTACAAGTACACAATCCCACC } \\
\text { F: }\end{array}$ & $\operatorname{GGC}\left(3^{*} 5\right)$ & 60 & $120-160$ & 7 & 5 & 3 & 5 & 1 & 5 & 0.77 \\
\hline DecSSR217 & $\begin{array}{l}\text { TCTGCAAACTGAGGTTCTTCTTC } \\
\text { R: } \\
\text { TTGCCAAACGAGACCATAGAGTA } \\
\text { F: }\end{array}$ & $\operatorname{TTC}\left(3^{*} 5\right)$ & 55 & $260-310$ & 4 & 1 & 1 & 3 & $\mathrm{x}$ & 1 & 0.41 \\
\hline DecSSR218 & $\begin{array}{l}\text { TATCTCTATCTGGGGATTGGAGC } \\
\text { R: AAACAAAACCAAATCGCGG } \\
\text { F: }\end{array}$ & $\operatorname{GCG}\left(3^{*} 6\right)$ & 60 & $140-160$ & 6 & 3 & 3 & 4 & 3 & 2 & 0.80 \\
\hline DecSSR221 & $\begin{array}{l}\text { ATCGACACTACTCTCGGCATAAC } \\
\text { R: GTATGTGGTGGAGGTAGTTGGG } \\
\text { F: }\end{array}$ & TCG $(3 * 5)$ & 60 & $120-140$ & 3 & 1 & 1 & 1 & 2 & 2 & 0.55 \\
\hline DecSSR222 & $\begin{array}{l}\text { GGTCATCACCGACTGGTTATTTA } \\
\text { R: } \\
\text { ACTTGACAAATCTCTGTCCCGTA }\end{array}$ & $\operatorname{GGC}\left(3^{\star} 5\right)$ & 55 & $130-140$ & 5 & 4 & 1 & 3 & 2 & 4 & 0.63 \\
\hline DecSSR224 & $\begin{array}{l}\text { F: AAGACGAAGCGAGCGTTG } \\
\text { R: CTTCCTCTCCTGGTCGTCCT }\end{array}$ & CGG $\left(3^{\star} 5\right)$ & 62 & $90-100$ & 2 & 1 & 2 & 1 & 1 & 2 & 0.33 \\
\hline DecSSR228 & $\begin{array}{l}\text { F: GTCGTCGAGCTTCCCGAG } \\
\text { R: CTGCTAGAGACGCGGAGC }\end{array}$ & $\operatorname{GCC}\left(3^{\star} 5\right)$ & 60 & $100-110$ & 3 & 2 & 1 & 2 & 1 & 2 & 0.51 \\
\hline
\end{tabular}




\section{Continued}

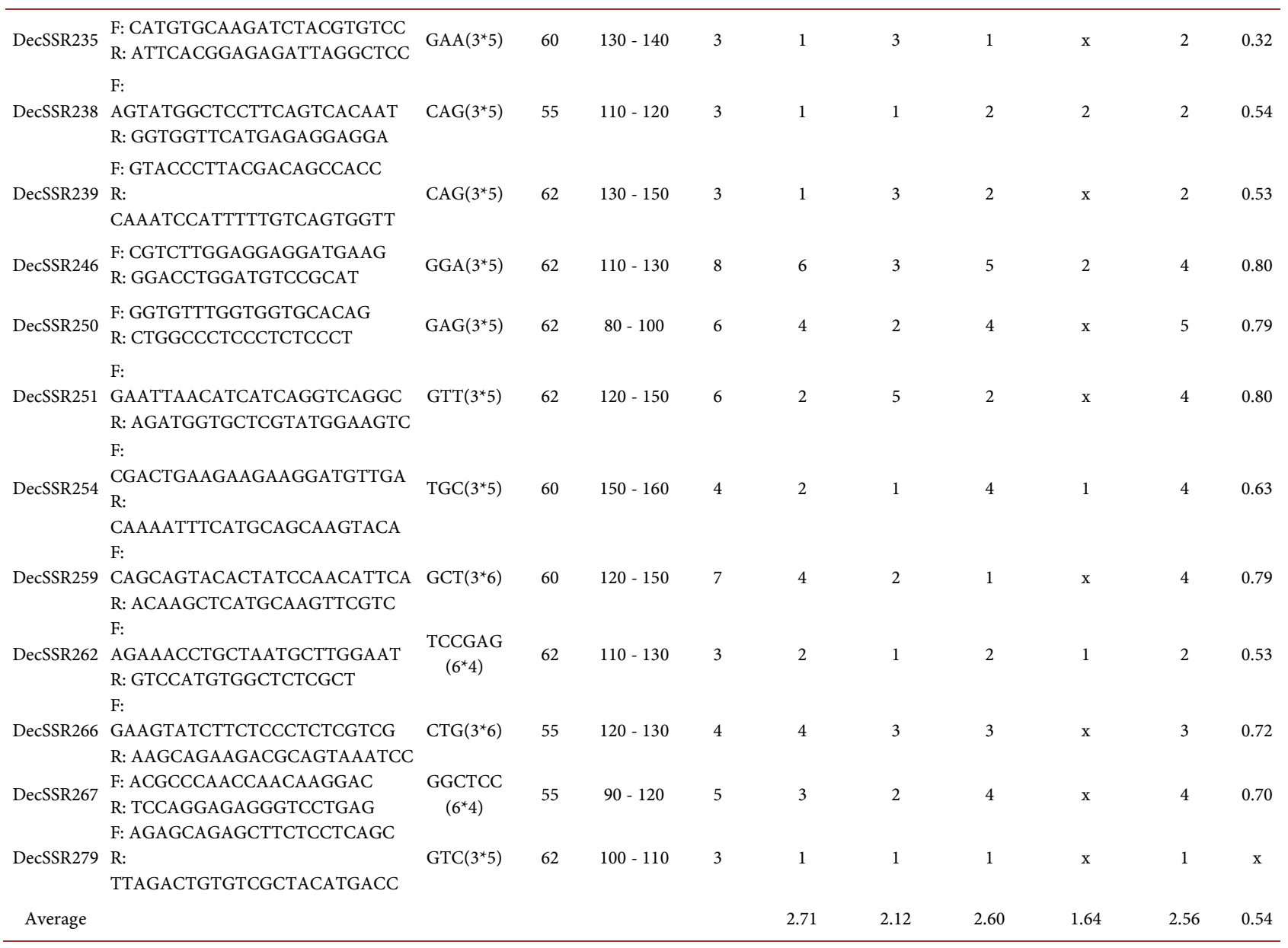

${ }^{a}$ Amplification temperature $\left({ }^{\circ} \mathrm{C}\right),{ }^{b} \mathrm{x}$ means no amplified PCR products NCBI deposit ID: 2306544.

amplified products were separated by electrophoresis through $3 \%$ agarose gels prior to vertical electrophoresis through $6 \%$ denaturing polyacrylamide gels stained with silver according to [17]. The product sizes were determined by comparison to those of a 10 bp DNA ladder (Invitrogen). Only the strongest bands were considered because the less intense bands in the polyacrylamide gels might have been stutter bands.

\subsection{Locus Function Annotation}

Function annotation of the unigenes containing the microsatellites DecSSR 202, DecSSR 203, DecSSR 218 and DecSSR 221 was conducted by searches against Pfam 31.0 database [18], using the online platform (http://pfam.xfam.org) with default parameters. For identification of probable orthologous genes, the transcript sequences were used as queries for BLASTn searches against Phytozome v12.0 ([19] www.phytozome.net) grass database using the default parameters. Expression profiles of the orthologous genes, from close related species (Setaria italica, Panicum virgatum and Sorghum bicolor), were also obtained in Phytozome v12.0. 


\subsection{Data Analysis}

For cross-amplification analysis, a genic SSR marker was considered transferable when a band of the expected size was amplified via PCR and an appropriate microsatellite pattern was observed.

As conventionally established [20], markers were treated as dominant due to tetraploid level of some accessions; thus, all analyses were based on the presence ( 1 or yes) or absence ( 0 or no) of a band in the polyacrylamide gels. The polymorphic informative content (PIC) of each marker was determined according to Anderson et al. [20] as follows:

$P I C_{i}=1-\sum_{j} p_{i j}^{2}$ where $p_{i j}$ is the frequency of the $j$ th genic marker for accession $i$ and the summation extends over all such patterns. Because of the categorical nature, the set of molecular data was analyzed using Multiple Correspondence Analysis (MCA) to detect structural organization of accessions, with graphical representation through $\mathrm{R}$ [21] with "FactoMiner and factoextra" packages.

As an additional means of validation, the genetic distance among accessions was quantified by the Jaccard's coefficient and the analysis was performed based on a binary matrix of molecular data. A rooted tree was constructed using the unweighted pair group method with arithmetic mean (UPGMA). Both analyses were performed in R [21]; we used the "vegan" package for Jaccard's coefficient and, the "cluster and phangorn" packages for UPGMA.

\section{Results}

\subsection{Genic Microsatellite Polymorphism and Transferability}

A total of 14,932 microsatellites (excluding mononucleotide repetitions) were identified in 14,822 transcripts, ranging from 12 to 240 nucleotides in length and possessing four to eleven motif repeats. Trinucleotide repeat motifs were the most common microsatellites, accounting for $61 \%$ of all identified, and (GCG) ${ }^{\star 5}$ and (CGC) ${ }^{\star} 5$ were the most frequent.

This set of microsatellites, a hundred genic SSR markers were selected and 34 amplified successfully in $U$. decumbens. Of these, 151 alleles were revealed, leading to a mean number of 4.4 alleles per locus (ranging from 1 for DecSSR186 and DecSSR279 to 13 for DecSSR212). Thirty-two microsatellite loci were polymorphic (86\%) among the seven $U$. decumbens accessions. The mean PIC value was 0.54 (range $0.12-0.81$ ) (Table 2). The most informative loci in this panel of SSR markers were DecSSR202, DecSSR212, DecSSR213, DecSSR218, DecSSR246, DecSSR251 (PIC $\geq 0.8$ ), and the lowest was DecSSR184 (0.12) (Table 2). The cross-amplification survey showed $100 \%$ of the polymorphic markers amplified PCR products in $U$. ruziziensis tetraploid, $97 \%$ in $U$. brizantha, and $46.9 \%$ in $U$. humidicola.

\subsection{Multiple Correspondence and Diversity Analysis}

The two dimensions of MCA explained approximately $33 \%$ of the total variance 
(Figure 1). The agamic complex composed by $U$. brizantha, $U$. decumbens and $U$. ruziziensis was closely aligned at crossing point of two axis in the graphic and the $U$. humidicola accession was positioned on the far right of dimension 1 (Dim1, Figure 1). Considering markers with 5\% contribution to variance, five alleles of five SSR markers are highlighted on MCA and they were the most important to separate H16 from agamic group, and may contribute to separate sexual and apomictic accessions.

UPGMA dendrogram showed three clusters (Figure 2). One cluster is formed by the three autotetraploid $U$. ruziziensis accessions, all of sexual mode of reproduction, and five $U$. decumbens accessions, in which four are sexual and diploid and one is apomictic and tetraploid (D61). The second cluster is composed by apomictic and tetraploid $U$. decumbens and $U$. brizantha accessions. This cluster can be divided in two subgroups, in which one subgroup contain all four $U$. brizantha accessions and the other subgroup, with the apomictic $U$. decumbens D07 and D62. Lastly, the third cluster contain the B. humidicola "BRS Tupi" (H16), the most dissimilar species evaluated.

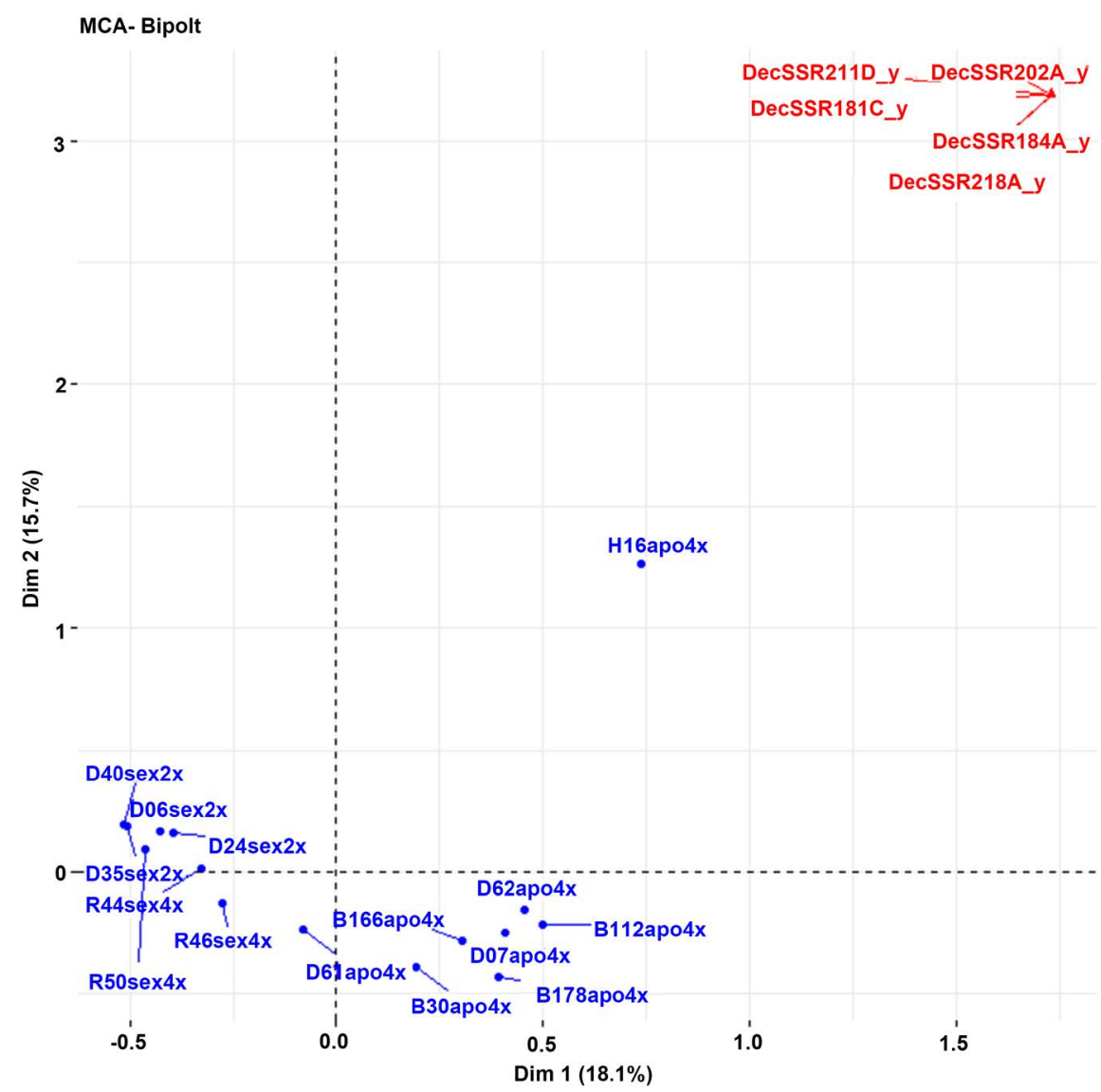

Figure 1. Multiple correspondence analysis of the 15 accessions of Urochloa spp. studied. Each accession is coded according ECG numbers (Table 1) followed by mode of reproduction designation (apo-apomictic or sex = sexual) and ploidy level ( $2 \mathrm{x}$-diploid and $4 \mathrm{x}$-tetraploid). Upper right corner shows the loci presenting more than $5 \%$ variance contribution in the first two dimensions (Dim). Axis numbers between parentheses are the proportion of variance explained in each dimension. 


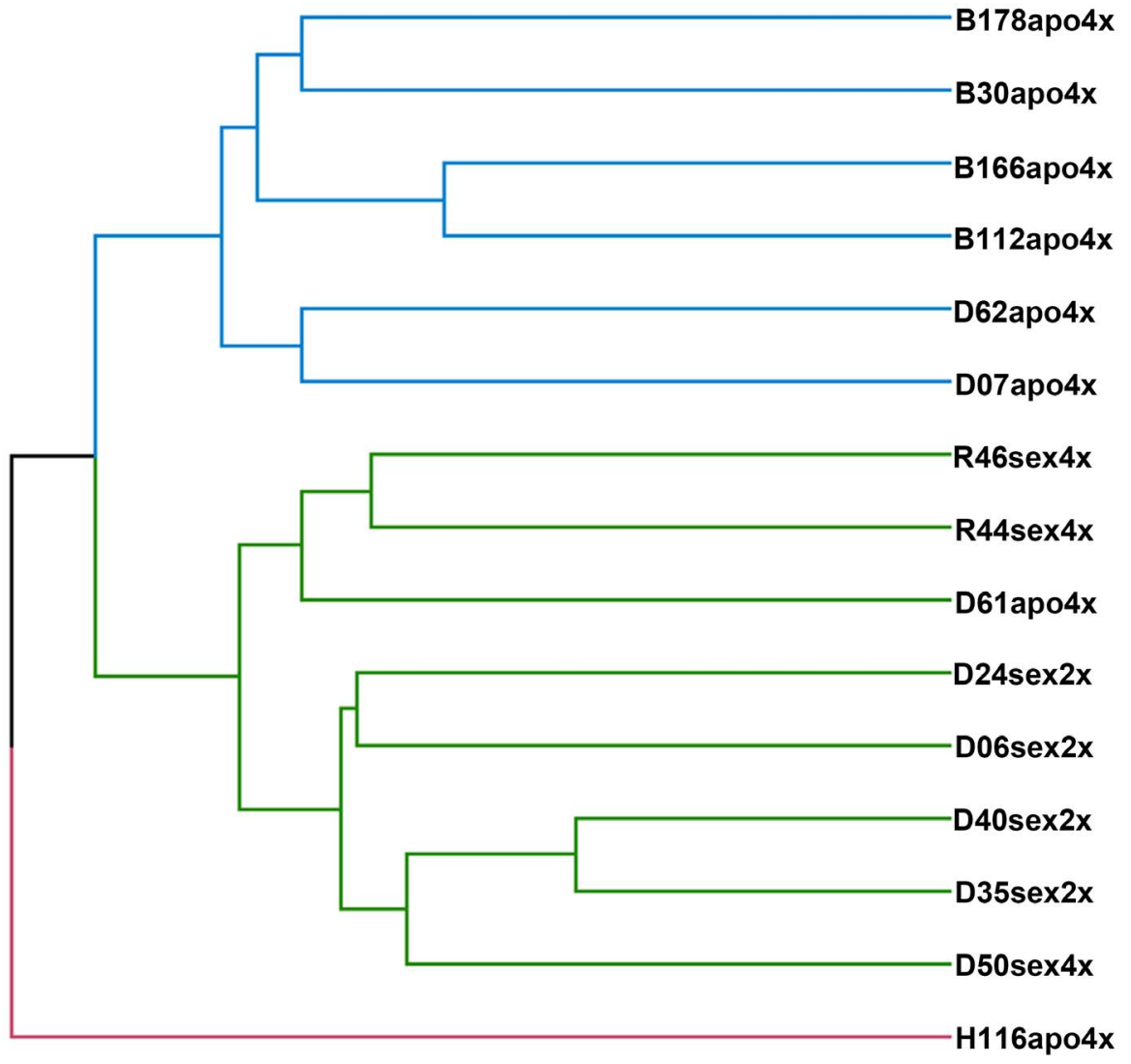

Figure 2. Rooted pair group method with arithmetic mean tree, based on the Jaccard dissimilarity index calculated from EST-SSR data, assembling 15 Urochloa accessions belonging to $U$. decumbens, $U$. brizantha and $U$. ruziziensis agamic complex and $U$. humidicola. EGC numbers in Table 1 identifies accessions, apo or sex identifies the mode of reproduction apomictic or sexual assignments, respectively, and $2 \mathrm{x}$ or $4 \mathrm{x}$ identifies the accession ploidy level. Comparison between mode of reproduction groups presented significance $(\mathrm{p}=8 \mathrm{e}-4)$ using multivariate analysis and correcting by step-down sequential correction Bonferroni.

Based on results of MCA and cluster analyses, some genic SSR were further investigated. For DecSSR202 locus, six alleles in $U$. decumbens were observed, four alleles in $U$. ruziziensis and one in $U$. brizantha. The unique allele amplified in apomictic $U$. brizantha accessions was also present in apomictic accessions of $U$. decumbens, but not in sexual ones and not in $U$. humidicola. The other five alleles observed in apomictic $U$. decumbens are also randomly present in sexual accessions. Loci DecSSR203, DecSSR218 and DecSSR221 show four, six and three alleles, respectively, and similarly for DecSSR202, the allele's presence varied individually in frequency between sexual or apomictic accessions. Adding DecSSR184 and DecSSR211, these SSR markers were the more important to divergence between accessions and species (Figure 2).

\subsection{Functional Annotation}

The transcript sequences, containing DecSSR202, DecSSR203, DecSSR218 and 
DecSSR221 SSRs were queried against Pfam and Phytozome databases for functional annotation (Table 3 ) and investigation of their orthologous genes expression patterns. None of these four unigenes presents similarity to the apospory-specific region (ASGR), sequenced by Conner et al. [22], nor they are meiosis-specific genes (Table 3). However, expression data for close related species (Setaria italica, Panicum virgatum and Sorghum bicolor) reveal high expression levels of DecSSR203 and DecSSR218 orthologous genes in different stages of panicle development, suggesting these genes could play a role on reproductive development in grasses.

\section{Discussion}

In the present study, trinucleotide repeat motifs were the most abundant form of microsatellite, consistent with other publications that obtained SSR markers using EST sequencing for different plant species [24] [25] [26]. The method used here has proved to be useful mostly because it is functionally-associated, which provides an effective means to develop molecular markers that target nucleotide diversity in conserved genic regions allowing a high degree of transferability between related species.

Amplification success of genic microsatellites (32\%) was lower than evidenced in previous studies using genomic microsatellite-enriched library as source for the development of primers [7] [27] [28] [29] [30]. Moreover, Silva et al. [8] obtained $88.9 \%$ success rate of PCR amplification for microsatellite loci generated based on partial de novo genome assembly of $U$. ruziziensis. Eujayl et al. [24] and Chagné et al. [32] also evidenced a low rate of amplification of EST-SSR compared with SSR markers isolated from total genomic DNA in wheat and pines, respectively. This lack or low amplification obtained for genic SSR could be explained by the quality of the primer pairs and/or the presence of introns at primer annealing regions. The low mean of alleles per locus (4.4 alleles/locus)

Table 3. Functional annotation of four loci potentially linked to apomixis in Urochloa and their probable orthologous loci in Setaria italica, Panicum virgatum and Sorghum bicolor.

\begin{tabular}{|c|c|c|c|c|c|}
\hline SSR locus & Protein name & $\begin{array}{l}\text { Pfam domain } \\
\text { number }\end{array}$ & $\begin{array}{c}\text { Pfam } \\
\text { E-value }\end{array}$ & $\begin{array}{l}\text { Probable orthologous } \\
\text { loci in grasses }\end{array}$ & $\begin{array}{l}\text { Blastn } \\
\text { E-value }\end{array}$ \\
\hline DecSSR202 & $\begin{array}{l}\text { Homeobox-leucine } \\
\text { zipper protein } \\
\text { ATHB-54-related }\end{array}$ & $\begin{array}{l}\text { PF00046 } \\
\text { PF02183 }\end{array}$ & $\begin{array}{l}2.3 e-17 \\
4.7 e-17\end{array}$ & $\begin{array}{c}\text { Seita.1G306100 } \\
\text { Pavir.Aa00462 } \\
\text { Sobic.004G251300 }\end{array}$ & $\begin{array}{l}0.00 \\
0.00 \\
0.00\end{array}$ \\
\hline DecSSR203 & $\begin{array}{l}\text { Protein of unknown } \\
\text { function }\end{array}$ & $\begin{array}{l}\text { PF04783 } \\
\text { PF04782 }\end{array}$ & $\begin{array}{l}6.0 e-22 \\
7.6 e-96\end{array}$ & $\begin{array}{c}\text { Seita.5G179100 } \\
\text { Pavir.Ea01929 } \\
\text { Sobic.003G168100 }\end{array}$ & $\begin{array}{l}0.00 \\
0.00 \\
0.00\end{array}$ \\
\hline DecSSR218 & $\begin{array}{l}\text { Splicing factor 3B } \\
\text { subunit 2-like }\end{array}$ & $\begin{array}{l}\text { PF04037 } \\
\text { PF04046 }\end{array}$ & $\begin{array}{l}7.1 e-36 \\
3.4 e-21\end{array}$ & $\begin{array}{c}\text { Seita.4G290900 } \\
\text { Pavir.Aa00053 } \\
\text { Sobic.010G278800 }\end{array}$ & $\begin{array}{l}3.3 e-75 \\
3.1 e-31 \\
2.0 e-65\end{array}$ \\
\hline DecSSR221 & $\begin{array}{c}\text { tRNA } \\
\text { (guanine(37)-N(1))- } \\
\text { methyltransferase }\end{array}$ & PF02475 & $1.2 \mathrm{e}-60$ & $\begin{array}{c}\text { Seita.J001500 } \\
\text { Pavir.Eb02431 } \\
\text { Sobic.007G058001 }\end{array}$ & $\begin{array}{c}0.00 \\
0.00 \\
2.0 \mathrm{e}-166\end{array}$ \\
\hline
\end{tabular}


was also evidenced in this work and corroborates the information reported as a disadvantage of genic SSR as they do tend to show a lower rate of polymorphism (in terms of allelic richness) than those derived from genomic libraries [23] [31] [32] [33] [34].

However, EST-SSR markers exhibit a great advantage over SSR markers developed via cloning and sequencing because they are more widely transferable between species and even genera [11], as confirmed in the present work. Although the proportion of transferability of genic SSR markers to species of the same agamic complex ( $U$. brizantha and $U$. ruziziensis) was similar to that obtained for SSR derived from genomic libraries (>90\%) [7] [8] [29], the proportion of transferability was higher in $U$. humidicola using genic SSR polymorphic primer pairs $(47 \%)$ than evidenced using SSR isolated from total genomic DNA (38\% [7]).

Interspecific crossings in Urochloa breeding seeks to combine main forage characteristics. Moreover, apomictic interspecific hybrids obtained after crosses allow heterosis fixation in a cultivar, which is desirable commercially [9]. Apomictic and sexual individuals are discriminated by embryo sac analysis and/or progeny tests, but both methods are time consuming and expensive. Molecular markers linked to mode of reproduction have been used in order to discriminate apomictic and sexual in offspring at the seedling stage [9] [35]. However, markers have performed inconsistently or have been unable to generate bands linked to apomixis in other crosses, no matter if intraspecific or interspecific. Recently, the primer pair p779/p780 was developed [36] and was linked to the apospory-specific genomic region (ASGR) in Pennisetum and Cenchrus species. This gene was tested in a diversity panel comprising four apomictic interspecific Urochloa hybrid cultivars and accessions (apomictic and sexual) of $U$. brizantha, $U$. decumbens, $U$. humidicola and Panicum maximum, and was broadly predictive for apomixis [9]. However, p779/p780 was not efficient as diagnostic marker for apomixis in interspecific hybrids when different apomictic accessions of $U$. brizantha were used as male parent at Embrapa Gado de Corte (L. Chiari, T. G. Déo, unpublished data). Markers associated to apomixis in Urochloa species have shown some specificity when they are applied to other species of the genus or applied to other accessions used in crosses, such as p779/p780 and GBS-derived KASP markers [9]; SCAR marker N14 [9] [37] and RAPD marker for apomixis in $U$. humidicola [38]. Those results are comprehensive and expected considering the ASGR has been mapped to a physical large hemizygous region of reduced recombination [39], resulting in inheritance of apospory as a single dominant Mendelian factor. Accordingly, the markers found in recent researches are linked but are not causative of characteristic mode of reproduction. Based on this premise, other associated loci should be revealed and must be studied. In this work, four genic SSR markers may be linked to apomixis in $U$. brizantha and $U$. decumbens. Further studies involving segregating progeny evaluations and markers are still necessary in intra and interspecific crosses in both species, 
since population structure may have caused spurious associations leading to false-positive observation [40].

\section{Conclusion}

The present study described the first effort to develop genic SSR markers based on Urochloa decumbens transcriptome. A set of 34 primer pairs have been developed, tested and transferred between Urochloa species of different modes of reproduction and ploidy. Overall, above $98 \%$ of polymorphic 32 genic SSR markers have been transferred to species of the same agamic complex and $47 \%$ to $U$. humidicola, a species with a distinct genomic structure. Our results also reinforce the evidences of broad cross-transferability of genic markers. This study provides new genic markers potentially useful and transferable to other Urochloa species that will add molecular information aiming at studies of genetic mapping, genetic association and genomic selection for economically important characteristics in this tropical grass forage.

\section{Acknowledgements}

The authors would like to thank the Associação para o Fomento à Pesquisa de Melhoramento de Sementes Forrageiras (Unipasto), Fundação de Apoio ao Desenvolvimento do Ensino, Ciência e Tecnologia do Estado de Mato Grosso do Sul (FUNDECT 0048/12), and the National Council for Scientific and Technological Development for financial support. The authors gratefully thank Sanzio Carvalho de Lima Barrios for providing the Urochloa genotypes used. First author is an undergraduate student from PIBIC-CNPq-EMBRAPA Program fellowship and Leonardo Rippel Salgado is postdoctoral fellow from DCR-CNPqFUNDECT Program fellowship.

\section{References}

[1] Valle, C.B., Jank, L. and Resende, R.M.S. (2008) Brachiaria Breeding. In: Resende, R.M.S., Jank, L. and Valle, C.B., Eds., Tropical Forages Breeding, Embrapa Gado de Corte, Campo Grande, 13-53.

[2] Pessoa-Filho, M., Azevedo, A.L.S., Sobrinho, F.S., Gouvea, E.G., Martins, A.M. and Ferreira, M.E. (2015) Genetic Diversity and Structure of Ruzigrass Germplasm Collected in Africa and Brazil. Crop Science, 55, 2736-3745. https://doi.org/10.2135/cropsci2015.02.0096

[3] Miles, J.W. (2007) Apomixis for Cultivar Development in Tropical Forage Grasses. Crop Science, 47, S238-S249. https://doi.org/10.2135/cropsci2007.04.0016IPBS

[4] Jank, L., Barrios, S.C., Valle, C.B., Simeão, R.M. and Alves, G.F. (2014) The Value of Improved Pastures to Brazilian Beef Production. Crop and Pasture Science, 65, 1132-1137. https://doi.org/10.1071/CP13319

[5] Valle, C.B. and Savidan, Y. (1996) Genetics, Cytogenetics, and Reproductive Biology of Brachiaria. In: Miles, J.W., Maass, B.L. and Valle, C.B., Eds., Brachiaria: Biology, Agronomy, and Improvement, EMBRAPA/CIAT, Cali, 147-163.

[6] Lutts, S., Ndikumana, J. and Louant, B.P. (1991) Fertility of Brachiaria ruziziensis in Interspecific Crosses with Brachiaria decumbens and Brachiaria brizantha-Meiotic 
Behavior, Pollen Viability and Seed Set. Euphytica, 57, 267-274. https://doi.org/10.1007/BF00039673

[7] Ferreira, R.C.U., Cançado, L.J., Valle, C.B., Chiari, L. and de Souza, A.P. (2016) Microsatellite Loci for Urochloa decumbens (Stapf) R.D. Webster and Cross-Amplification in Other Urochloa Species. BMC Research Notes, 9, 152. https://doi.org/10.1186/s13104-016-1967-9

[8] Silva, P.I.T., Martins, A.M., Gouvea, E.G., Pessoa-Filho, M. and Ferreira, M.E. (2013) Development and Validation of Microsatellite Markers for Brachiaria ruziziensis Obtained by Partial Genome Assembly of Illumina Single-End Reads. BMC Genomics, 14, 17. https://doi.org/10.1186/1471-2164-14-17

[9] Worthington, M.L., Heffelfinger, C., Bernal, D., Quintero, C., Zapata, Y.P., Perez, J.G., Vega, J.D., Miles, J., Dellaporta, S. and Tohme, J. (2016) A Parthenogenesis Gene Candidate and Evidence for Segmental Allopolyploidy in Apomictic Brachiaria decumbens. Genetics, 203, 1117-1132.

https://doi.org/10.1534/genetics.116.190314

[10] Ishigaki, G., Gondo, T., Ebina, M., Suenaga, K. and Akashi, R. (2010) Estimation of Genome Size in Brachiaria Species. Grassland Science, 56, 240-242. https://doi.org/10.1111/j.1744-697X.2010.00200.x

[11] Bouck, A. and Vision, T. (2007) The Molecular Ecologist's Guide to Expressed Sequence Tags. Molecular Ecology, 16, 907-924. https://doi.org/10.1111/j.1365-294X.2006.03195.x

[12] Salgado, L.R., Lima, R., Santos, B.F., Shirakawa, K.T., Vilela, M.A., Almeida, N.F., Pereira, R.M., Nepomuceno, A.L. and Chiari, L. (2017) De Novo RNA Sequencing and Analysis of the Transcriptome of Signalgrass (Urochloa decumbens) Roots Exposed to Aluminum. Plant Growth Regulation, 83, 157-170. https://doi.org/10.1007/s10725-017-0291-2

[13] Thiel, T. (2001) MISA: MIcroSAtellite Identification Tool. Version 1.0. In: MISA: MicroSAtellite Identification Tool. Leibniz Institute of Plant Genetics and Crop Plant Research. http://pgrc.ipk-gatersleben.de/misa/

[14] Untergasser, A., Nijveen, H., Rao, X., Bisseling, T., Geurts, R. and Leunissen, J.A.M. (2007) Primer3Plus, an Enhanced Web Interface to Primer3. Nucleic Acids Research, 35, W71-W74. https://doi.org/10.1093/nar/gkm306

[15] Lyons, E., Pedersen, B., Kane, J., Alam, M., Ming, R., et al. (2008) Finding and Comparing Syntenic Regions among Arabidopsis and the Outgroups Papaya, Poplar, and Grape: CoGe with Rosids. Plant Physiology, 148, 1772-1781. https://doi.org/10.1104/pp.108.124867

[16] Doyle, J.J. and Doyle, J.L. (1987) A Rapid DNA Isolation Procedure for Small Quantities of Fresh Leaf Tissue. Phytochemical Bulletin, 19, 11-15.

[17] Creste, S., Tulmann Neto, A. and Figueira, A. (2001) Detection of Single Sequence Repeat Polymorphisms in Denaturing Polyacrylamide Sequencing Gels by Silver Staining. Plant Molecular Biology Reporter, 19, 299-306. https://doi.org/10.1007/BF02772828

[18] Finn, R.D., Coggill, P., Eberhardt, R.Y., Eddy, S.R., Mistry, J., Mitchell, A.L., Potter, S.C., Punta, M., Qureshi, M., Sangrador-Vegas, A., Salazar, G.A., Tate, J. and Bateman, A. (2016) The Pfam Protein Families Database: Towards a More Sustainable Future. Nucleic Acids Research, 44, D279-D285. https://doi.org/10.1093/nar/gkv1344

[19] Camacho, C., Coulouris, G., Avagyan, V., Ma, N., Papadopoulos, J., Bealer, K. and Madden, T. (2009) BLAST+: Architecture and Applications. BMC Bioinformatics, 
10, 421. https://doi.org/10.1186/1471-2105-10-421

[20] Goodstein, D.M., Shu, S., Howson, R., Neupane, R., Hayes, R.D., Fazo, J., Mitros, T., Dirks, W., Hellsten, U., Putnam, N. and Rokhsar, D.S. (2012) Phytozome: A Comparative Platform for Green Plant Genomics. Nucleic Acids Research, 40, D1178D1186. https://doi.org/10.1093/nar/gkr944

[21] Anderson, J.A., Churchill, G.A., Autrique, J.E., Tanksley, S.D. and Sorrells, M.E. (1993) Optimizing Parental Selection for Genetic Linkage Maps. Genome, 36, 181-186. https://doi.org/10.1139/g93-024

[22] R Development Core Team (2016) R: A Language and Environment for Statistical Computing. Version 3.3.4. R Foundation for Stat. Comput., Vienna.

[23] Conner, J.A., Goel, S., Gunawan, G., Cordonnier-Pratt, M.M., Johnson V.E., et al. (2008) Sequence Analysis of Bacterial Artificial Chromosome Clones from the Apospory-Specific Genomic Region of Pennisetum and Cenchrus. Plant Physiology, 147, 1396-1411. https://doi.org/10.1104/pp.108.119081

[24] Eujayl, I., Sorrells, M.E., Baum, M., Wolters, P. and Powell, W. (2002) Isolation of EST-Derived Microsatellite Markers for Genotyping the A and B Genomes of Wheat. Theoretical and Applied Genetics, 104, 399-407. https://doi.org/10.1007/s001220100738

[25] Varshney, R.K., Sigmund, R., Borner, A., Korzun, V., Stein, N., Sorrels, M.E., Langridge, P. and Graner, A. (2005) Interspecific Transferability and Comparative Mapping of Barley EST-SSR Markers in Wheat, Rye and Rice. Plant Science, 168, 195-202. https://doi.org/10.1016/j.plantsci.2004.08.001

[26] Kaur, S., Cogan, N.O., Pembleton, L.W., Shinozuka, M., Savin, K.W., Materne, M. and Forster, J.W. (2011) Transcriptome Sequencing of Lentil Based on SecondGeneration Technology Permits Large-Scale Unigene Assembly and SSR Marker Discovery. BMC Genomics, 12, 265. https://doi.org/10.1186/1471-2164-12-265

[27] Jungmann, L., Sousa, A.C.B., Paiva, J., Francisco, P.M., Vigna, B.B.Z., Valle, C.B., Zucchi, M.I. and Souza, A.P. (2009) Isolation and Characterization of Microsatellite Markers for Brachiaria brizantha (Hochst. ex A. Rich.) Stap. Conservation Genetics, 10, 1873-1876. https://doi.org/10.1007/s10592-009-9839-7

[28] Jungmann, L., Vigna, B.B.Z., Paiva, J., Sousa, A.C.B., Valle, C.B., Laborda, P.R., Zucchi, M.I. and Souza, A.P. (2009) Development of Microsatellite Markers for Brachiaria humidicola (Rendle) Schweick. Conservation Genetics Resources, 1, 475-479. https://doi.org/10.1007/s12686-009-9111-y

[29] Vigna, B.B., Alleoni, G.C., Jungmann, L., Valle, C.B. and Souza, A.P. (2011) New Microsatellite Markers Developed from Urochloa humidicola (Poaceae) and Cross Amplification in Different Urochloa Species. BMC Research Notes, 4, 523. https://doi.org/10.1186/1756-0500-4-523

[30] Santos, J.C.S., Barreto, M.A., Oliveira, F.A., Vigna, B.B.Z. and Souza, A.P. (2015) Microsatellite Markers for Urochloa humidicola (Poaceae) and Their Transferability to Other Urochloa Species. BMC Research Notes, 8, 83-95. https://doi.org/10.1186/s13104-015-1044-9

[31] Chabane, K., Ablett, G.A., Cordeiro, G.M., Valkoun, J. and Henry, R.J. (2005) EST versus Genomic Derived Microsatellite Markers for Genotyping Wild and Cultivated Barley. Genetic Resources and Crop Evolution, 52, 903-909. https://doi.org/10.1007/s10722-003-6112-7

[32] Chagné, D., Chaumeil, P., Ramboer, A., Collada, C., Guevara, A., Cervera, M.T., et al. (2004) Cross-Species Transferability and Mapping of Genomic and cDNA SSRs in Pines. Theoretical and Applied Genetics, 109, 1204-1214. 
https://doi.org/10.1007/s00122-004-1683-Z

[33] Jungmann, L., Vigna, B.B., Boldrini, K.R., Sousa, A.C., Valle, C.B., Resende, R.M., Pagliarini, M.S., Zucchi, M.I. and Souza, A.P. (2010) Genetic Diversity and Population Structure Analysis of the Tropical Pasture Grass Brachiaria humidicola Based on Microsatellites, Cytogenetics, Morphological Traits, and Geographical Origin. Genome, 53, 698-709. https://doi.org/10.1139/G10-055

[34] Boldrini, K.R., Pagliarini, M.S. and Valle, C.B. (2009) Meiotic Behavior of a Nonaploid Accession Endorses $\mathrm{x}=6$ for Brachiaria humidicola (Poaceae). Genetics and Molecular Research, 8, 1444-1450. https://doi.org/10.4238/vol8-4gmr679

[35] Worthington, M.L. and Miles, J.W. (2015) Reciprocal Full-Sib Recurrent Selection and Tools for Accelerating Genetic Gain in Apomictic Brachiaria. In: Budak, H. and Spangenberg, G., Eds., Molecular Breeding of Forage and Turf, Springer International, Cham, 19-30. https://doi.org/10.1007/978-3-319-08714-6_3

[36] Akiyama, Y., Goel, S., Conner, J.A., Hanna, W.W., Yamada-Akiyama, H. and Ozias-Akins, P. (2011) Evolution of the Apomixis Transmitting Chromosome in Pennisetum. BMC Evolutionary Biology, 11, 289.

https://doi.org/10.1186/1471-2148-11-289

[37] Zorzatto, C., Chiari, L., Araújo Bitencourt, G., Valle, C.B., Leguizamón, G.O.C., Schuster, I. and Pagliarini, M.S. (2010) Identification of a Molecular Marker Linked to Apomixis in Brachiaria humidicola (Poaceae). Plant Breeding, 129, 734-736. https://doi.org/10.1111/j.1439-0523.2010.01763.x

[38] Pedraza Garcia, F.P. (1995) Genetic Mapping of Apomixis Gene using RAPD Makers. PhD Thesis, Universidad Nacional de Colombia, Palmira, Valle del Cauca.

[39] Ozias-Akins, P., Roche, D. and Hanna, W.W. (1998) Tight Clustering and Hemizygosity of Apomixis-Linked Molecular Markers in Pennisetum squamulatum Implies Genetic Control of Apospory by a Divergent Locus That May Have No Allelic Form in Sexual Genotypes. Proceedings of the National Academy of Sciences, 95, 5127-5132. https://doi.org/10.1073/pnas.95.9.5127

[40] Zhao, K., Aranzana, M.J., Kim, S., Lister, C., Shindo, C., Tang, C., Toomajian, C., Zheng, H., Dean, C., Marjoram, P. and Nordborg, M. (2007) An Arabidopsis Example of Association Mapping in Structured Samples. PLOS Genetics, 3, e4. https://doi.org/10.1371/journal.pgen.0030004 